DOI https://doi.org/10.30525/978-9934-26-004-9-118

\title{
КУЛЬТУРОЛОГІЧНИЙ ПІДХІД У ДОСЛІДЖЕННІ ПРОМИСЛОВОГО ДИЗАЙНУ
}

\author{
Шапаренко О. М. \\ стариий викладач кафедри рисунку і живопису \\ Київського національного університету будівництва і архітектури \\ м. Київ, Украӥна
}

Тривалий час об'єкти промислового дизайну розглядалися здебільшого 3 позицій притаманних модернізму: функціональності, конструктивності, утилітарності. Тобто першочергове значення приділялося хоча й дуже важливим, але формальним якостям. Не зважаючи на те, що на зміну модерну прийшли постмодерн та метамодерн, наблюдаємо стійке домінування модерністських критеріїв оцінки і «модерністського проекту» у нашій свідомості.

Причини криються в тому, що саме в першій половині XX ст. було закладено фундамент професії, основи теорії промислового дизайну та напрацьовано базову методологію.

Тема набуває особливої актуальності з огляду на те, що починаючи 3 80-х років XX ст. у дизайн-проектуванні почав поступово впроваджуватися міждисциплінарний підхід i ця тенденція стрімко поширюється до нашого часу. В даному контексті саме культурологічний підхід до вивчення об'єктів промислового дизайну та теорії проектування може дати цікаві результати, окреслити нові горизонти розвитку професії.

Дослідження культурологічного характеру у галузі дизайну [2; 3] демонструють принципову цінність такого підходу. Предметом дослідження культурології є сукупність питань про розвиток і діяльність культури, як особливого образу існування людини; явищ культурної взаємодії; методів культурного пізнання світу; спадкоємності ціннісних ідеалів поколінь і культурного досвіду взагалі.

Антропологічний аспект культурологічних досліджень об'єктів дизайну дозволяє відкрити нові смислові шари та вписати ці об'єкти в загальну картину світу, повернувши сучасним технологічним речам синкретичність часів «протодизайну». Соціологічний та аксіологічний аспекти дозволяють виявити механізми соціокультурної динаміки 
пристосовно до промислового дизайну та прогнозувати розвиток перспективних напрямів.

Сьогодні вже мало проектувати речі під гаслами модернізму («форма йде за функцією») чи постмодернізму (форма йде за емоцією). XXI століття ставить нові виклики і задачі перед професією. Нові аспекти соціологічного та гуманістичного характеру піднімають питання про більш широке розуміння етичності, екологічності та інших факторів, про необхідність перегляду проектних задач.

Речі, якими ми користуємося, $є$ результатом свідомого вибору i відображенням нашої системи цінностей. Саме культурологічний підхід в дослідженнях промислового дизайну дозволить найти відповіді на гострі питання сьогодення, сформулювати актуальні принципи проектування та критерії оцінки.

\title{
Література:
}

1. Моль А. Социодинамика культуры : пер. с фр. / Б.В. Бирюков и др. Изд. 3-е. M.:URSS. ЛКИ, 2008. 405 с.

2. Суджич Д. Язык вещей / Пер. с англ. М.: Strelka Press, 2013. 240 c.

3. Хиллер Бивис. Стиль ХХ века / Б. Хиллер. М.: СЛОВО / SLOVO, 2004. $240 \mathrm{c}$.

DOI https://doi.org/10.30525/978-9934-26-004-9-119

\section{ШРИФТ ЯК ОДИН 3 НАЙВАЖЛИВІШИХ ЗАСОБІВ КОМУНІКАЦІї В ДИЗАЙНІ ПУБЛІКАЦІЙ}

\author{
Яковець I. O. \\ доктор мистеитвознавства, доцент, \\ професор кафедри дизайну \\ Музиченко В. М. \\ викладач-методист, \\ завідувач відділення дизайну \\ Черкаського державного бізнес-коледжу \\ м. Черкаси, Украӥна
}

Оформлення тексту $€$ одним 3 центральних питань дизайну друкованих видань. На суто функціональному рівні завдання дизайнера дотримуватися читабельності, ієрархії та ясності у подачі вербальної інформації. Але шрифт передає ще й невербальне повідомлення. 